\title{
Experimental Study on Mechanism of Establishing Collateral Circulation
}

\section{Part II : Drug Effects on Peripheral Blood Circulation \\ - From Viewpoint of Enzymatic Study -}

\author{
Kimio Sawada \\ From the Department of Surgery, Kansai Medical University Osaka, Japan \\ (Director ; Prof. M. Yamamoto M.D.)
}

\section{Introduction}

In 1959 Ebashi et al ${ }^{1}$ pointed out that serum Creatine Phosphokinase (CPK) was markedly elevated among patients with progressive muscular dystrophy (Duchenne). It was believed that CPK, mostly contained in the skeletal muscles of the four extremities, flows out quantatively into the blood stream if degenerative changes take place in the muscles.

The author has been studying the mechanism of establishing collateral blood vessels at the time of acute arterial obstruction.

It has been widely recognized that anticoagulants are definitely effective in thrombosis and embolism and myocardial infarction, not only for prevention but also as one of the most reliable therapies in these diseases. These drugs have been gradually and widely accepted in Japan, and have contributed to decreased mortality in obstructive vascular disease, though not without critical comments by some groups. Unfortunately, however, the pharmacological mechanism of these anticoagulants has not yet been cleared to our satisfaction. Their main effect, i. e. prolonging blood coagulation time, is sufficient to explain the fact that primarily developed thrombus will not become larger and secondary thrombus may be prevented by use of these drugs, but it fails to answer the question of whether these drugs can cure the thrombus or embolus existing before admimistration. On the other hand, it is well known that quantitative intravenous administration of Low Molecular Weight Dextran (LMWD) is quite effective in thromboangitis obliterans Bürger. Based on the fact that Heparin and Heparinoids are therapeutically effective even in acute arterial occlusion, in which embolus or thombus already existed before the administration of these drugs, the author endeavored to find out whether or not the mechanism of these drugs is of metabolic origin. 
In the previous paper, the author pointed out that one of the important factors in deciding the prognosis of arterial obstructive disease was whether or not sufficient collateral circulation was established, and concluded that pulsatile blood flow contributed most effectively to the satisfactory estalishment of collateral circulation.

This paper is a part of the study, mainly reporting the following: 1) analysis of peripheral blood flow in cases of acute arterial obstruction by measuring enzymes such as CPK and GOT in peripheral blood as well as in peripheral muscle, 2) influence of anticoagulant group such as Heparin. and Heparinoid on establishment of collateral blood vessels.

\section{Methods}

Experimental Animals and Procedures:

Mongrels of $10 \mathrm{Kg}$ body weight average were used in this experiment. Under intravenous sodium Nembutal anesthesia, $30 \mathrm{mg}$ per $\mathrm{Kg}$ body weight, and intratracheal tube airway, the abdominal aorta was exposed through a median incision, doubly ligated and occluded just above the aortic bifurcation. (Fig. 1.)

Experimental dogs were then divided into 5 groups, A, B, C, D, and E : (Table 1.) Group A : no drug was given

Group B : To this group, only physiological saline solution $50 \mathrm{ml} / \mathrm{Kg} /$ day was administrated after occlusion.

Group C: After occlusion 500 Units of Heparin per Kg body weight per day was administrated in addition to normal saline solution at $50 \mathrm{ml} / \mathrm{Kg} /$ day.

Group D : $50 \mathrm{ml}$ of $6 \%$ LMWD in saline solution per $\mathrm{Kg}$ body weight per day was administrated after occlusion.

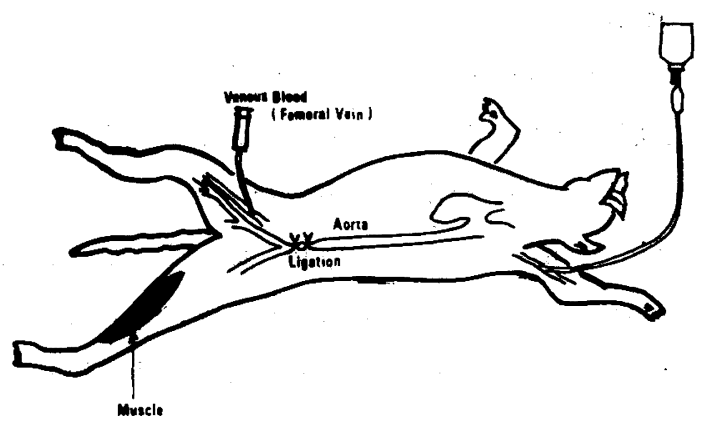

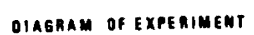

Fig. 1

Table 1

Group A No drug was given
Group B Saline $50 \mathrm{ml} / \mathrm{Kg} /$ day
Group C Saline $50 \mathrm{ml}$ and Heparin $500 \mathrm{u} / \mathrm{Kg} /$ day
Group D LMW Dextran $50 \mathrm{ml} / \mathrm{Kg} /$ day
Group E Saline $50 \mathrm{ml}$ and Dextran Sulfate $60 \mathrm{mg} / \mathrm{Kg} /$ day


Group E : $60 \mathrm{mg}$ of Dextran Sulfate together with $50 \mathrm{ml}$ of normal saline solution per $\mathrm{Kg}$ body weight per day administrated to this group,

Comparative studies were done with these 5 groups.

Blood samples were collected from time to time from both femoral veins and serum GOT and CPK values were carefully checked. Activity of CPK in the muscles was also measured by collecting 2 grams of calf muscle in parallel with blood examinations.

GOT was measured by Ritmann-Frankel method, Serum CPK by Noda, Kuby \& Lardy method. 2) ${ }^{-5}$ ) Intramuscular CPK activity was measured as follows; 2 grams of calf muscle was homogenized together with 9 volumes of $0.02 \mathrm{M} \mathrm{NaHCO}_{3}$, in Potter-Elvehjem Teflon homogenizer chilled with ice cubes. The material was then centrifuged at $6000 \mathrm{G}$ for 20 minutes in refrigerated centrifuge. Then CPK activity was checked using the method of Noda, Kuby \& Lardy. ${ }^{6}$ )

\section{Results of Experiments}

1) GOT and CPK Activity in the Serum :

A) Goup A : As shown in Fig. 2 and Table 2,3, both serum CPK and serum GOT rose gradually for the first 24 hours. GOT activity showed no significant elevation after that, but CPK activity continued to rise even $48 \mathrm{hrs}$. after occlusion,

B) Group B : With this group, as shown in Fig. 3 and Table 2, 3, both serum CPK and GOT activity kept rising after occlusion, most marked between 6 and 12 hours of occlusion.

C) Group C: With this group receiving Heparin, changes of serum GOT values were nittle different from Group B, but serum CPK values showed marked elevation for the first $24 \mathrm{hrs}$., then leveled off. (Fig. 4 \& Table 2,3).

D) Group D: In this group receiving LMWD as shown in Fig. 5 and Table 2,3. serum

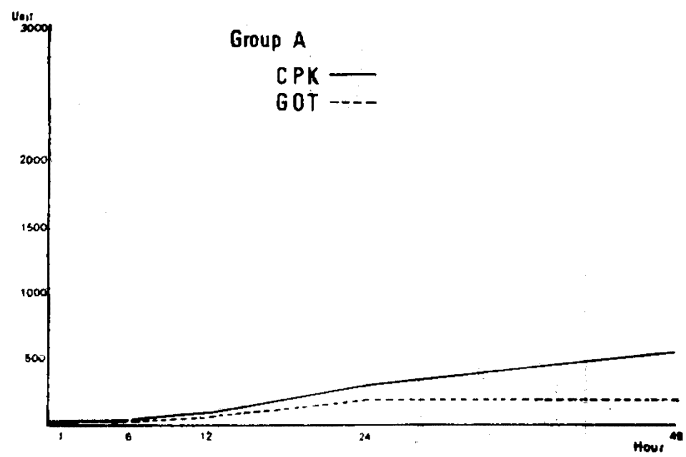

Fig. 2

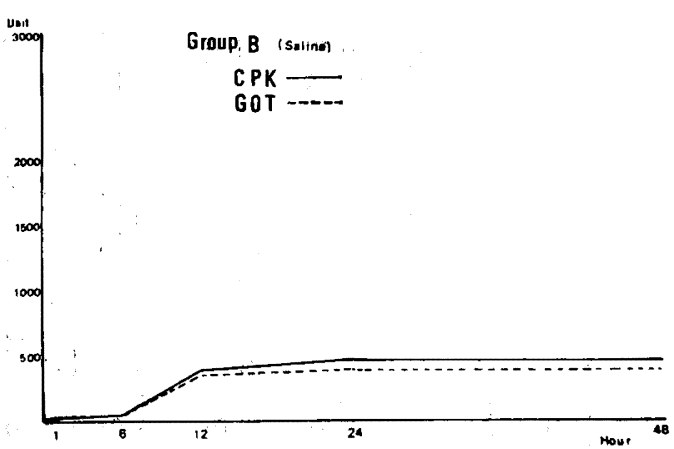

Fig. 3 
Tab1e 2 The effect of HEPARIN, LMWD anb D.S. on the serum GOT level after femoral artery occlusion

\begin{tabular}{|c|c|c|c|c|c|c|c|c|c|c|c|}
\hline Hour & & Before & 1 & 2 & 3 & 4 & 5 & 6 & 12 & 24 & 48 \\
\hline Group A & & 18 & 17 & 15 & 18 & 18 & 13 & 10 & 45 & 183 & 195 \\
\hline Group B & 20 & \pm 9.46 & $46.6 \pm 39.97$ & $48.6 \pm 41.56$ & $50.4 \pm 38.9$ & $52.8 \pm 47.28$ & $58.4 \pm 41.66$ & $63.4 \pm 51.27$ & $358 \pm 152.10$ & $388.6 \pm 126.33$ & $389 \pm 111.59$ \\
\hline $\begin{array}{c}\text { Group } C \\
\mathrm{P}^{*}\end{array}$ & 21. & $\begin{array}{l}.2 \pm 9.17 \\
\text { N.S. }\end{array}$ & $\begin{array}{l}37.6 \pm 23.92 \\
\text { N.S. }\end{array}$ & $\begin{array}{l}38 \pm 19.72 \\
\text { N.S. }\end{array}$ & $\begin{array}{l}58 \pm 28.21 \\
\text { N.S. }\end{array}$ & $\begin{array}{l}73 \pm 15.54 \\
\text { N.S. }\end{array}$ & $\begin{array}{l}84.8 \pm 8.42 \\
\text { N.S. }\end{array}$ & $\begin{array}{l}96 \pm 23.11 \\
\text { N.S. }\end{array}$ & $\begin{array}{l}315 \pm 58.98 \\
\text { N.S. }\end{array}$ & $\begin{array}{l}425 \pm 59.32 \\
\text { N.S. }\end{array}$ & $\begin{array}{l}\text { 413. } 33 \pm 62.36 \\
\text { N.S. }\end{array}$ \\
\hline $\begin{array}{c}\text { Group } D \\
P^{*}\end{array}$ & 19.3 & $\begin{array}{l}33 \pm 8.21 \\
\text { N.S. }\end{array}$ & $\begin{array}{l}31.5 \pm 10.15 \\
\text { N.S. }\end{array}$ & $\begin{array}{c}25.33 \pm 10.87 \\
\text { N.S. }\end{array}$ & $\begin{array}{l}40.66 \pm 13.69 \\
\text { N.S. }\end{array}$ & $\begin{array}{l}51 \pm 24.05 \\
\text { N.S. }\end{array}$ & $\begin{array}{l}52 \pm 30.21 \\
\text { N.S. }\end{array}$ & $\begin{array}{l}142.66 \pm 101.14 \\
\text { N.S. }\end{array}$ & $\begin{array}{l}314 \pm 11.04 \\
\text { N.S. }\end{array}$ & $\begin{array}{l}600 \pm 191.3158 \\
\text { N.S. }\end{array}$ & $\begin{array}{c}583.33 \pm 115.56 \\
\text { N.S. }\end{array}$ \\
\hline $\begin{array}{c}\text { Group } E \\
\mathrm{P}^{*}\end{array}$ & 9.6 & $\begin{array}{l} \pm 6.49 \\
\text { N.S. }\end{array}$ & $\begin{array}{l}15.6 \pm 5.60 \\
\text { N.S. }\end{array}$ & $\begin{array}{l}18.2 \pm 4.16 \\
\text { N.S. }\end{array}$ & $\begin{array}{l}16.4 \pm 4.49 \\
\text { N.S. }\end{array}$ & $\begin{array}{l}18.2 \pm 3.12 \\
\text { N.S. }\end{array}$ & $\begin{array}{l}20.4 \pm 6.15 \\
\text { N.S. }\end{array}$ & $\begin{array}{l}61.2 \pm 36.103 \\
\text { N.S. }\end{array}$ & $\begin{array}{l}26.6 \pm 157.19 \\
\text { N.S. }\end{array}$ & $\begin{array}{l}603.6 \pm 203.53 \\
\text { N.S. }\end{array}$ & $\begin{array}{l}418 \pm 151.31 \\
\text { N.S. }\end{array}$ \\
\hline
\end{tabular}

* For the calculation of the statistical significance from the controls (Group B )

N.S. not significant $(0.05<P)$.

Table 3 The effct of HEPARIN, LMWD and D.S. on the serum $\mathrm{CPK}$ level after femoral artery occlusion

\begin{tabular}{|c|c|c|c|c|c|c|c|c|c|c|}
\hline Hour & Before & 1 & 2 & 3 & 4 & 5 & 6. & 12 & 24 & 48 \\
\hline Group A & 29 & 30 & 39 & 38 & 58 & 60 & 23 & 96 & 300 & 558 \\
\hline Group B & $20.6 \pm 7.08$ & $30.5 \pm 18.89$ & $32.0 \pm 19.69$ & $32.8 \pm 12.60$ & $32.7 \pm 11.91$ & $39.3 \pm 13.63$ & $46.6 \pm 15.25$ & $385.2 \pm 214.99$ & $457 \pm 245.25$ & $448.2 \pm 143.32$ \\
\hline$\underset{\mathrm{P}^{*}}{\text { Group } \mathrm{C}}$ & $\begin{array}{l}23.2 \pm 8.58 \\
\text { N.S. }\end{array}$ & $\begin{array}{l}32.9 \pm 15.40 \\
\text { N.S. }\end{array}$ & $\begin{array}{l}\text { 41. } 0 \pm 8.39 \\
\text { N.S. }\end{array}$ & $\begin{array}{c}51.30 \pm 3.28 \\
P<0.05\end{array}$ & $\begin{array}{c}64.4 \pm 9.83 \\
\mathrm{P}<0.01\end{array}$ & $\begin{array}{l}73.1 \pm 23.49 \quad 8 \\
P<0.05\end{array}$ & $\begin{array}{l}84.3 \pm 27.29 \\
\mathrm{P}<0.05\end{array}$ & $\begin{array}{c}312.34 \pm 116.79 \\
\text { N.S. }\end{array}$ & $\begin{array}{c}628 \pm 114.42 \\
\text { N.S. }\end{array}$ & $\begin{array}{c}707.33 \pm 120.74 \\
P<0.05\end{array}$ \\
\hline $\begin{array}{c}\text { Group D } \\
\text { P. }\end{array}$ & $\begin{array}{c}24.33 \pm 8.17 \\
\text { N.S. }\end{array}$ & $\begin{array}{c}25.0 \pm 6.68 \\
\text { N.S. }\end{array}$ & $\begin{array}{c}28.33 \pm 10.78 \\
\text { N.S. }\end{array}$ & $\begin{array}{l}33.66 \pm 14.81 \\
\text { N.S. }\end{array}$ & $\begin{array}{l}46.3 \pm 18.55 \\
\text { N.S. }\end{array}$ & $\begin{array}{l}60.33 \pm 33.18 \\
\text { N.S. }\end{array}$ & $\begin{array}{c}108 \pm 10.03 \\
P<0.01\end{array}$ & $\begin{array}{l}596 \pm 298.65 \\
\text { N.S. }\end{array}$ & $\begin{array}{c}1126 \pm 617.55 \\
\text { N.S. }\end{array}$ & $\begin{array}{c}876.5 \pm 39.23 \\
P<0.01\end{array}$ \\
\hline $\begin{array}{c}\text { Group } \\
P^{*}\end{array}$ & $\begin{array}{c}24.7 \pm 11.76 \\
\text { N.S. }\end{array}$ & $\begin{array}{c}31.8 \pm 12.95 \\
\text { N.S. }\end{array}$ & $\begin{array}{c}41.0 \pm 11.04 \\
\text { N.S. }\end{array}$ & $\begin{array}{c}40.6 \pm 12.91 \\
\text { N.S. }\end{array}$ & $\begin{array}{l}51.2 \pm 25.65 \\
\text { N.S. }\end{array}$ & $\begin{array}{c}51.2 \pm 15.63 \\
\text { N.S. }\end{array}$ & $\begin{array}{c}87.5 \pm 25.94 \\
P<0.05\end{array}$ & $\begin{array}{l}409 \pm 235.18 \\
\text { N. S. }\end{array}$ & $\begin{array}{c}2011 \pm 669.24 \\
P<0.01\end{array}$ & $\begin{array}{c}1109.8 \pm 440.39 \\
P<0.05\end{array}$ \\
\hline
\end{tabular}

* For the calculation of the statistical significance from the controls (group B).

N.S. not significant $(0.05<P)$. 


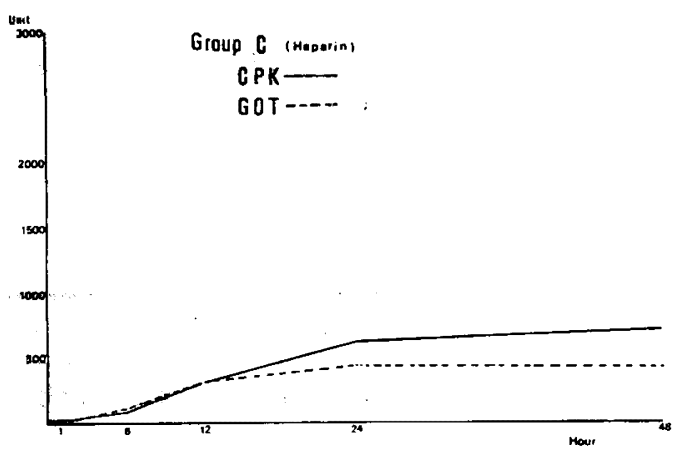

Fig. 4

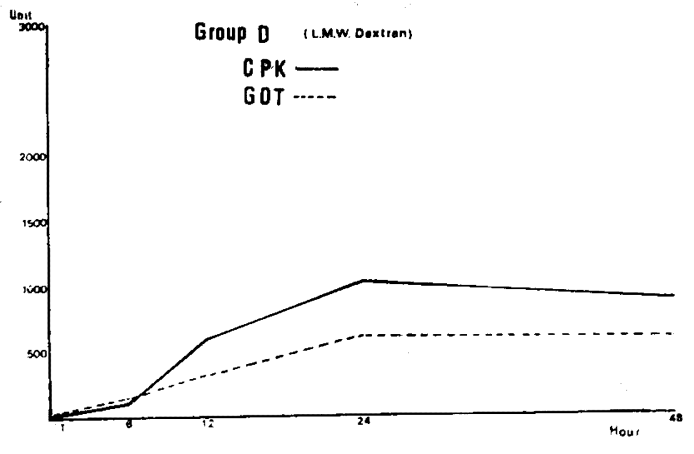

Fig. 5

GOT kept rising at a constant rate for the first 24 hours, then gradually decreased. Serum CPK values rose promptly until 6 to $12 \mathrm{hrs}$. of occlusion, and decreased thereafter.

E) Group F : With this group to which Dextran Sulfate was administered, serum GOT changes were similar to Group D. Maximum GOT values were recorded at 24 hours after occlusion, but the decrease after $24 \mathrm{hrs}$. was more conspicuous than in Group D. Serum CPK values rose rapidly between 6 and 24 hours of occlusion, and then decreased abruptly as shown in Fig. 6 and Table 2,3.

2) CPK Activity in the Muscles :

CPK activity in the muscles showed marked decrease immediately after occlusion of the abdominal aorta, presenting opposite feature (Mirror Image) to that in the serum, which was true with all of the five groups. CPK decreased among Groups $\mathrm{C}, \mathrm{D}$ and $\mathrm{E}$ at definitely more prompt rate than in groups $\mathrm{A}$ and $\mathrm{B}$. Intramuscular CPK activity among groups C, D and E decreased rapidly in the first 12 hours of occlusion, to approximately $30 \%$ of original values. The rate of

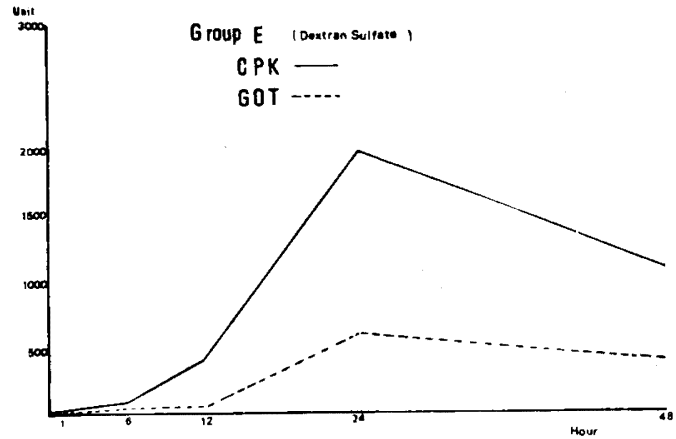

Fig. 6

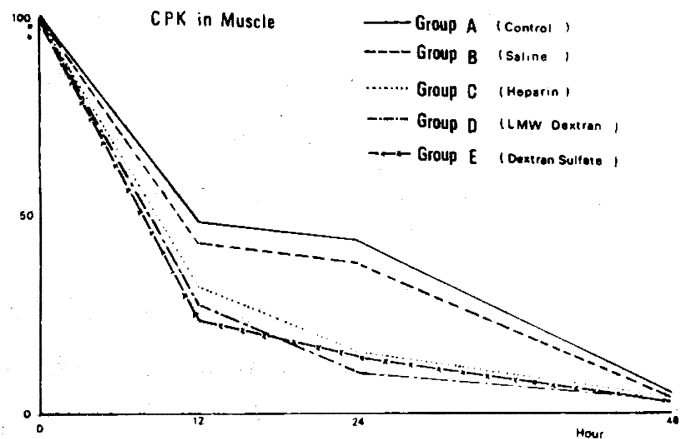

Fig. 7

Supplement to J.Kansai Med. Sch., Vol. 25, March 1973 
decrease later was rather slow, but only about $10 \%$ of the original was measured 48 hrs. after occlusion, which was true with all of the 5 groups (Fig. $7 \&$ Table 4).

Table 4 The effect of HEPARIN, LMWD, and D.S. on the muscle CPK level after femoral artery occlusion

\begin{tabular}{|c|c|c|c|c|}
\hline Hour & Before & 12 & 24 & 48 \\
\hline Group A & $100 \%$ & $47.8 \pm 1.4 \%$ & $44.2 \pm 1.2 \%$ & $4.2 \pm 0.8 \%$ \\
\hline \multicolumn{5}{|l|}{ Group B } \\
\hline Saline $50 \mathrm{ml} / \mathrm{Kg} /$ Day & $100 \%$ & $43.6 \pm 1.9 \%$ & $38.9 \pm 1.0 \%$ & $3.9 \pm 0.7 \%$ \\
\hline \multicolumn{5}{|l|}{ Group C } \\
\hline $\begin{array}{l}\text { Saline } 50 \mathrm{ml} \text { and Heparin } 500 \mathrm{u} / \mathrm{Kg} / \mathrm{Day} \\
\quad \text { P* }\end{array}$ & $100 \%$ & $\begin{array}{l}30.9 \pm 2.2 \% \\
\quad P<0.05\end{array}$ & $\begin{array}{l}15.7 \pm 1.1 \% \\
P<0.01\end{array}$ & $\begin{array}{l}3.3 \pm 0.6 \% \\
\text { N.S. }\end{array}$ \\
\hline \multicolumn{5}{|l|}{ Group D } \\
\hline $\begin{array}{l}\text { LMWD Dextran } 50 \mathrm{ml} / \mathrm{Kg} / \text { Day } \\
\quad \mathrm{P}^{*}\end{array}$ & $100 \%$ & $\begin{array}{l}22.7 \pm 1.8 \% \\
\quad P<0.05\end{array}$ & $\begin{array}{l}12.4 \pm 0.9 \% \\
\quad \mathrm{P}<0.01\end{array}$ & $\begin{array}{l}2.4 \pm 0.4 \% \\
\text { N.S. }\end{array}$ \\
\hline \multicolumn{5}{|l|}{$\begin{array}{l}\text { Group E } \\
\text { Saline } 50 \mathrm{ml}\end{array}$} \\
\hline $\begin{array}{l}\text { and Dextran Sulfate } 60 \mathrm{mg} / \mathrm{Kg} / \text { Day } \\
\text { P* }\end{array}$ & $100 \%$ & $\begin{array}{l}26.9 \pm 2.4 \% \\
\quad \mathrm{P}<0.05\end{array}$ & $\begin{array}{l}10.9 \pm 0.7 \% \\
P<0.01\end{array}$ & $\begin{array}{l}3.0 \pm 0.5 \% \\
\text { N.S. }\end{array}$ \\
\hline
\end{tabular}

* For the calculation of the statistical significance from the controls (group B)

N.S. not significant $(0.05<P)$.

\section{Discussion}

Prognosis of acute arterial obstructive diseases, untreated, is usually poor, with the patients'lives, as well as their affected limbs exposed to danger. Even successful establishment of blood circulation to the affected limbs sometime fails to improve the unfavorable prognosis if surgery is not performed immediately after obstruction. On the other hand, prognosis of chronic arterial obstructive diseases, in which the obstructive process takes place gradually, has been reported as quite favorable if satisfactory collateral blood circulation be established by surgical procedures, even though surgery is performed at a rather late stage. Late patency is thus often assured with chronic cases.

One of the reasons why prognosis of the acute arterial obstructive diseases is so poor is as follows: Metabolic products such as lactic acid and pyruvic acid accumulate in the muscles, the blood supply to which has been disturbed on account of acute obstruction, and these metabolic products flow into the blood stream on re-establishment of 
circulation, resulting in metabolic acidosis. In addition, insufficient oxygen supply changes permeability of muscle cell membranes, resulting in excessive outflow: of potassium into the blood. This hyperpotassemia compromises cardiac function. This is believed to be the so-called declamping shock. As compared with chronic arterial obstruction, poor establishment of collateral circulation is noted with acute cases, and moreover, artificial stoppage of peripheral blood circulation for the purpose of performing surgery usually causes double damage to peripheral tissues, which are already suffering from a shortage of oxygen, so naturally these tissues are sometimes irreversibly changed. In such cases patients must be treated carefully with as much consideration for metabolic mechanism of the peripheral tissues as for the vascular obstruction itself. It is quite reasonable that Spencer et al ${ }^{7)}$ emphasized the importance of late embolectomy being performed only when no degeneration or necrosis of muscles could be found.

It is easily imagined that prognosis of acute arterial obstructive diseases may be markedly improved by any'procedure performed to encourage development of collateral blood circulation, to prevent accumulation of metabolic products in the peripheral tissues, and to stimulate recovery and activation of the affected cells. It is, however, practically very difficult to decide whether the affected limbs can endure surgical procedures. Indications for surgery in acute arterial obstructive disease have been discussed from time to time, but no definite indications have been established yet.

Recent progress in enzyme chemistry has become important in understanding metabolic mechanisms in peripheral tissues. Enzyme chemistry has made it possible to analyse metabolism at the cell level. Changes of enzymatic activity in the serum usually indicates the degree of cellular degeneration, and thus enzymatic studies have been widely accepted in the field of clinical research.

Examination of Aldolase ${ }^{8)}$ or Succinic Dehydrogenase ${ }^{9}$ ) has been used for sometime as indicators of muscle cell degeneration in cases of acute arterial obstruction. Recently changes of Glutamic Oxalacetic Transaminase (GOT), Glutamic Pyruvic Transminase (GPT) and Creatine Phosphokinase (CPK) have been thought to be more important, and they are more and more utilized as laboratory methods are simplified.

GOT can be obtained from any tissue of the body, but is mostly contained in heart muscle, then the liver, and then skeletal muscles. GPT is mostly found in the liver and comparatively little is found in skeletal muscles of the four extremities. CPK is mostly contained in the skeletal muscles of the four extremities and it is belived to 
react most sharply and accurately to degenerative changes of the muscles. This fact has been proved both experimentally and clinically. ${ }^{10)}$ Prognosis is extremely poor if CPK in the serum rises promptly after arterial obstrucion. Possibility of saving the affected limb by means of surgical re-establihment of circulation is believed also to be poor if serum CPK values are slow in returning to normal. Thus, investigation of enzymatic activity is very important for comprehending the actual state of peripheral blood circulation and changes in the peripheral tissues.

Careful investigation of our experimental data tells us that CPK activity in the returning femoral venous blood showed constant increase even after 48 hours of occlusion in groups A and B to which only normal saline solution was administered. Conversely, CPK activity in the returning femoral venous blood showed maximum value approximately 24 hours after occlusion and a tendency to decrease after that in groups to which Heparin or Heparinoid was administrated.

Results of CPK activity in the muscle indicate that it began to decrease immediately after arterial obstruction, the rate being rather slow in groups $A$ (no drug was given) and $B$ (saline administration), and rapid with the other groups receiving either Heparin or Heparinoid. The tendency to rapid decrease was most marked during the first 24 hours of occlusion. From these results it is said that CPK activity in the muscle presents the so-called mirror image (Spiegelbild) of that in the serum, and this suggests movement of CPK from muscle cells into the blood stream.

As for movement of enzymes into blood stream from the affected cells, GOT in cases of myocardial infarction and CPK in progressive muscular dystrophy have already been reported. These changes of enzyme activity may be influenced by several factors such as amount of enzyme in the cells, difference of enzyme localization in the cells, permeability of cell membrane, metabolic rate in the blood and existence of nonactivating meterials in the blood. Condition of peripherel blood circulation may also have great influence on the amount of enzymes escaping into the blood stream from the affected cells.

Judging from our experimental results intramuscular GOT and CPK definitely move into the blood stream after occlusion more rapidly among the groups receiving Heparin, Dextran Sulfate or LMWD, in comparison with the control and saline groups. This is because more and better peripheral circulation was assured with the Heparin or Heparinoid groups.

It is of course too early to conclude that these effects of Heparin and Heparinoid are favorable in humans, and naturally other opinions must be considered. However, 
it is quite interesting to review reports by others that LMWD infusion was extremely effective in cases of re-implantation of amputated limbs, and that the limbs were successfully reanastomosed even 7 hours after amputation with the help of LMWD infusion. This fact encourages us to believe that administration of either Heparin or Heparinoid is very useful.

Contemporary studies of Heparin, Dextran Sulfate and LMWD have shown their favorable influence on the peripheral circulation, and they are believed to improve peripheral dynamic blood flow mainly by preventing sludging in the capillary vessels.

Effects of Heparin on myocardial infarction have been repeatedly reported. In addition to its 'original effect of preventing secondary infarction, antiinflammatory effects by lipolytic activity and antihyaluronidase activity, vasodilating effect and cardiotonic effect have also been reported. In 1968 Groover et al ${ }^{11}$ ) reported delay in oxyhemoglobin desaturation rate by use of Heparin and pointed out conspicuous oxygen saving effects of Heparin. $\mathrm{O}^{\prime} \mathrm{Brien}^{12}$ ) reported that Heparin had a great influence on the permeability of cells and he concluded that Heparin increased permeability of cell membranes. Smith ${ }^{13}$ ) reported that administration of Heparin to patients with acute renal insufficiency resulted in marked improvement of renal blood flow with diuresis and prolongation of their lives.

Likewise we have observed oxygen saving effects, though temporary, when Heparin, Heparinoid or LMWD were administered. Based on these facts we should like to emphasize the significance and importance of intra-arterial administration of Heparin and/ or Heparinoid in cases of peripheral vascular disturbances.

As far as Endotoxin Shock is concerned, hyperbaric oxygen therapy has proved to be quite effective, and also infusion with Heparin or Dextran is always reported to be effective ${ }^{\left.14)^{15}\right)}$. These facts help when we consider oxygen consumption mechanism in living bodies.

C de Duve ${ }^{16}$ ) and others introduced lysosome, which has an important role at the time of cellular autolysis caused by damage to the cells. Plasmin, Heparin and Heparinoid are known to labilize the lysosome. When those drugs are used together with anti-cancer drugs, autolysis of cancer cells is accelerated and anti-cancer effects are reinforced. Judging from these effects, Heparin, Heparinoid and Dextran help autolysis of degenerated cells and hasten demarcation of necrotic parts.

Though effects of Heparin and Heparinoid in cases of cases of arterial obstruction have been known widely, only little of their mechanism of action has been unveiled so far. The author examined degrees of peripheral cell degeneration at time of arterial 
obstruction by quantatively measuring activity of enzymes (mainly CPK). It was found that Heparin and/or Heparinoid accelerated early flowing of these enzymes into the blood stream.

\section{Summary}

The effect of LMWD Heparin and Heparinoid on peripheral circulation in cases of acute arterial obstruction was studied in dogs by quantitatively measuring activity of emzymes.

Results are summarized as follows:

1) CPK activity in the returning femoral venous blood showed constant tendency to increase after occlusion in group B to which only normal saline solution was administered.

2) CPK activity in the returning femoral venous blood showed maximum value approximately 24 hours after occlusion and a tendency to decrease after that in groups C, D, E to which Heparin, LMW or Heparinoid was administered.

3) CPK activity in muscle showed tendency to decrease after arterial obstruction in all groups.

4) Intramuscular GOT and CPK definitely move into the blood st ream more rapidly after occlusion among the groups receiving Heparin, LMWD or Heparinoid in comparison with the group receiving only saline.

5) This is because better peripheral circulation was assured with the groups receiving Heparin, LMWD or Heparinoid.

\section{Acknowledgment}

In accomplishing the present paper the author wishes to express his greatest gratitude to Prof. M. Yamamoto M.D., D. M. Sc., and assistant Prof, J. Takeda M.D., D. M. Sc., for their valuable advice and encouraging guidance. Also the author wishes to express his thanks to the staff of this laboratory for their friendly collaboration.

\section{References}

1) Ebashi, S.et al. : High creatine phoshokinase activity of sera of progressive muscular dystrophy., J. Biochem., 46:103, 1959.

2) Kuby, S. A. et al. : Adenosinetriphoshate-creatine transphosphorylase. I. Isolation of the crystalline enzyme from rabbit muscle., J. Biol. Chem., 209:191, 1954.

3) Noda, L. et al, : Adenosinetriphosphate-creatine transphosphorylase. II. Homogeneity and physicochemical properties., J. Biol. Chem., 209:203, 1954. 
4) Kuby, S. A.et aI. : Adenosine triphosphate-creatine transphosphorylase. III. Kinetic studies., J. Biol. Chem., $210: 65,1954$.

5) Noda, L. et al. : Adenosinetriphosphate-creatine transphosphorylase. IV. Equilibrium studies., J. Biol. Chem., $210: 83,1954$.

6) Ebashi, S. and Akabori, S. : Rinsyô kôso gaku. (Creatine phosphokinase) 356, Asakurasyoten. (Tokyo), 1964. (in Japanese)

7) Spencer, F.C., and Eiseman, B. : Delayed arterial embolectomy- a new concept., Surg., $55: 64,1964$.

8) Yamashiro, M. : Sisi no Kyĉseidômyakuheisoku ni okeru Kessei "aldolase" no hendou ni tuite., Gekanoryoiki, $7: 1525,1959$. (in Japanese)

9) Sugaya, Y. : Sisi no Zikkenteki-Kyûseidômyakuheisoku ni okeru Massôbusosiki-Kohakusandassuisokassei no hendou ni tuite., J. J.S.S., 66:435, 1965. (in Japanese)

10) Kusaba, A. et al. : Kyûseidômyakuheisokusyô no yogohantei no men kara mita Creatine phosphokinase sokutei no igi., Geka, $31: 1141,1969$. (in Japanese)

11) Groover, M. E., : Heparin and oxygen consumption., Angiology, 19:299, 1968.

12) O'Brien, J. R. . : The effect of heparin on the early stages of blood coagulation., J. Clin. path., $13: 93,1960$.

13) Smith, P.K. : Anticoagulants in irreversible acute renal failure., The Lancet, 28 : $1360,1968$.

14) Fukunishi, H. : Studies on cause of shock following replantation of amputated extremity., J. Nara Med. Ass., $19: 127,1968$. (in Japanese)

15) Mehl, R. L. et al. : Treatment of Toxemia after extremity replantation., Arch. Surg., 89 : 871, 1964.

16) Duve, C. et al. : Tissue fractionation studies., Biochem. J., $60: 604,1955$. 